\title{
Sound Governance in Case of Mamminasata Metropolitan Development Area in South Sulawesi Province
}

\author{
Firdaus
}

\author{
Magister Program of Development Administration, Hasanuddin University \\ firdaus.daus6666@gmail.com
}

\begin{tabular}{|l|l|l} 
Received: March 2016 & Accepted: March 2016 & Published: May 2016
\end{tabular}

\begin{abstract}
The direction of development in Indonesia has strongly integrated with the concept of good governance started from the strengthening of international market that is both imperialist and colony thereby contradicting to the tradition of developing countries. This leads to the establishment of sound governance as an alternative concept to improve the government's capacity to innovate in policy and administration. The development of Mamminasata Metropolitan area in South Sulawesi province experiences difficulties in implementing the coordination, integration, synchronization and cannot accommodate the whole event in order to realize the interconnection of development across districts/ cities, whereas the central government makes this as a National Strategic Areas (KSN) and leading area in the East Indonesia. This study aims to explore and analyze the sound governance practices in the development program of Mamminasata Metropolitan area focusing on five dimensions, namely process, structure, values, management, and policy. The results show that 1) in the process dimension, the stakeholders involved in the Mamminasata development program establish inter-regional cooperation and coordinate externally and internally of the area ranging from planning to the implementation of development activities; 2) in the structure dimension, the government has established clear organization and regulation in regulating the development process. 3) in the value dimension, Mamminasata development program is based on the responsiveness of local government and has up-holded justice in accordance with the potential of each area; 4) in the management dimension, the government personnel has already had knowledge about the Mamminasata concept, but they are still experiencing problems in the use of technology because of limited resources; and 5) in the policy dimension, the government has encouraged the public to participate directly in policy making and implementation of development programs. Therefore, it can be concluded that the five dimensions of sound governance has been practiced in the Mamminasata Metropolitan area development.
\end{abstract}

Keywords: development, Mamminasata, sound governance 


\section{INTRODUCTION}

Development is a process of dynamic change to transform a country into advance condition. The development in a developing country is aimed at building up the elements and increasing the social-economic aspects. The growing of the social economic elements of a country will not happen if there is no both cooperation and participation from the civil society. Therefore, the public bureaucracy should involve their civil society actively within the development program of the country (Weidner, 1970). It needs an innovative system of administration to make sure that the development program meets the goal within the minimum time and resources (Katz, 1970).

Innovation in the case of development program is decided by the overall civil society through the growth of democratic politic system. The development administration is occupied to find a complex institution, a management system, and the governance process to reach the objective of the development program. Responding the demand of the civil society on the development program, it needs to adjust the increasingnumber of bureaucracy and the complexity of the governance function (Gant, 1979).

It needs to conduct a reformation in case of both institution and public management as the efforts to actualize the good governance in the context of a public service that is oriented in both the needs and the prosperity of the civil society (Batubara, 2006). However, on the other hand, it is stated by Achidsti (2011) that the development in the developing country i.e. Indone- sia whose root is in the concept of a good governance is contradictive to the direction of the national development. It is because the concept of the good governance is so based on the international market strengthening that ruling out the domestic economic strengthening. This kind of concept put the premise on the market-based approach to allocate and to manage public resources (Osborne, 2010). That situation contradicts to the national culture and it influences the tradition of the governance of the developing country that may poorly affect to the country because of the imperialist and colonial intention from the politic-economic elites. Because of the deficiency in the concept of good governance, it pushes up the realization of the concept of sound governance as an alternative way to actualize innovative governance in both its policy and administration (Farazmand, 2004).

A strong era of globalization needs innovations in governance. Innovations in governance are essential in adapting to a rapidly changing world environment. Associated with innovation, Farazmand (2004: 19) says that "Innovation is a key to sound governance and innovation in policy and administration is central to sound governance as well". Innovation is the key to sound governance, while the innovations in policy and administration are central to sound governance. Without the innovation policy and administration, then the administration (governance) signs in foul and ineffective conditions, it loses capacity of governance, and it becomes the targets of criticism and failure as well. 
Cooperation in development is the key to the current changes in the governance and management systems (Sangkala, 2011). The policies of decentralization and regional autonomy in Indonesia have implications for changes in the form of intergovernanceal relations. The implications of those changes were the relationship between the central governance to local governance and among local governances (Pratikno, 2007: 31). Developing countries have a lot of cooperation in development planning because the various problems encountered cannot be addressed in development planning only based on the boundaries of administrative areas. Many internal decisions of a district, a city or a province often associated with the problems beyond the borders so that the inter-regional cooperation is indispensable in addressing the problems of cross-border administrative regions (Keban, 2007). Therefore, the governance with the concept of sound governance requires the active participation of the civil society, including the issue of metropolitan governance which is becoming a global problem in the provision of municipal services (Farazmand, 2004).

Related to the innovation in development, there have been many studies of innovation from various perspectives, such as the innovation made in the field of technology and industry could reduce income inequality among regions. This research resulted in the finding of a positive relationship between innovations made and the impact of regional growth (Oughton, 2002). Therefore, the innovation is the most important key of the success of an organization to make a positive contribution as well as the advantages of competition (Hartmann, 2006). In addition, understanding of innovation in governance from the perspective of learning shows that technological innovations in public services require different managerial and organizational improvements (Parnaa \& Nick, 2007). This can be illustrated that an innovation in a logistics technology is significantly and positively influenced by the encouragement of the organization, the quality of human resources, the environmental uncertainty, and the governance support (Lin, 2007). That is why innovation cannot be separated from the organization, the resources and the use of technology.

From various research findings described above, it can be stated that the innovation can be run with the cooperation, motivation and strategic action. Moreover, this needs managerial and organizational changes, the desire and ability of the organization to perform innovation, human resources, governance supports, organizational structure changes, and administrative barriers that play a role in the development of innovation in local governance. Therefore, it needs to analyze innovations with different perspectives related to the innovation in the local governance (Noor, 2013). Thus, it is very relevant to conduct research on innovations made by local governances using the concept of sound governance that differentiates it from previous studies.

Sound governance requires ongoing innovation in policy and administrative processes, 
structures, and value systems. A governance applying the concept of good governance believes three elements, namely the governance itself, the civil society, and the private sectors. However, the concept of sound governance has one more additional element that play a central role in dealing with the impact of globalization, namely international element. Those fourth aspects were instrumental in strengthening governance that is known as sound governance. The sound governance has ten dimensions comprising: 1) process; 2) structure; 3) awareness and values; 4) constitutions; 5) organizations and institutions; 6) managements and performances; 7) policies; 8) sectors; 9) the strength of the impact of globalization and international issues, and 10) ethics, accountability and transparency that should be interrelated and interact dynamically to each other (Farazmand, 2004).

Related to the problems of development in developing countries, such as the construction that has been done in an area of Metropolitan, Mamminasata, at the beginning of its construction, HM Amin Syam as the South Sulawesi governor at the moment said that the development of the region implemented the concept of Mamminasata which is an acronym of Makassar, Maros, Sungguminasa/ Gowa and Takalar. This regional development was done through a cooperation to actualize a public intention in promoting and supporting potencies of each district or city and in facing various challenges and difficulties in order to achieve a leading comfortable region in eastern Indonesia in 2020 (Fajar, 2005).
Based on previous researches, the development of the metropolitan region Mamminasata has constraints on the commitment and the coordination among local governments' elements are still low. It is caused by an inequality of the development among regions. This causes an area feeling aggrieved because it covers so many areas that leads a remote control range among three districts and one city (Nasution, 2006). This was confirmed in the report of Regional Government (LPPD) of the South Sulawesi Government in 2007 which revealed that the Mamminasata Metropolitan Development Cooperation Agency (BKSPMM) has not been able to accommodate overall development activities to achieve interconnectivity across districts/ cities yet. In addition, the coordination in the preparation process of a spatial planning and Mamminasata Metropolitan integrated area is not conducted well (LPPD, 2009).

Meanwhile, the implementation of interregional cooperation in Indonesia has become the spotlight of the central government. In the Government Work Plan (RKP) in 2015, it was explained that the cooperation among the regions in the terms of public services has not shown significant results and has not been considered as one of the public service mechanism in resolving conflict yet. As in Mamminasata regional development program, the role of Mamminasata Metropolitan Development Cooperation Agency (BKSPMM) has not been implemented optimally in the terms of coordination, integration and synchronization of cross-regional developments, and 
control and supervision (RKP, 2012). From these data it can be stated that the development of Mamminasata metropolitan region has not been in line with the expectations yet.

In addition, a research on the sound governance had ever been undertaken by Hidayat (2015) which used three dimensions of the sound governance in the public service. The study found those three dimensions have been running well, however there are still shortcomings in the research because it cannot define the concept of the sound governance as a whole yet. Whereas Farazamand (2004: 10) explains that there is an important dimension to define the concept of the sound governance: structures, processes, values, policies and management. In addition, the sound governance had ever been examined by Holidin \& Handini (2014) using the ten dimensions. His research found that the dimensions of the sound governance have not been entirely actualized in the management innovation to revitalize traditional markets and street vendors in Surakarta. It is reflected as the government does not establish new institutions to take over management of traditional markets, but it remains under the control of the pre-existing official market institution.

The sound governance had ever also been investigated by Nugraha (2012). The results showed that in designing policies of Regional Civil Servants Candidate Selection (CPNSD) should be done by merit-based and corruptionfree governance. It needs to choose a sound perspective with four foot five-dimensional pattern. The four legs mentioned before are the govern- ment, the private sector, the civil society and the international powers. While the five dimensions cover processes, institutions, values, policies and management. However, in this study only deepen a discussion on the existing dimension of policy of the sound governance. Furthermore, Tjahjanulin (2011) carried out a research on inter-regional cooperation in the perspective of the sound governance among Sleman, Bantul and Yogyakarta regions. This study discusses the policy dimension but it does not review several other dimensions contained in the sound governance. Therefore, based on the previous research applying the concept of the sound governance, it is very interesting for the author to conduct a research implementing the five important dimensions to formulate the concept of sound governance. The author undertakes this study related on the Mamminasata metropolitan area development. This study aims at exploring and analyzing the dimensions of the sound governance in the Mamminasata metropolitan area development, South Sulawesi province.

\section{RESEARCH METHODS}

In solving the formulation of the problems and explaining the dimensions of the sound governance practices, it is necessary to take the appropriate measures. This study was designed systematically based on the facts accurately in interpreting and analyzing the Mamminasata metropolitan development areas in South Sulawesi province. This research was conducted using qualitative approach with case study strategy 
(Creswell, 2014), which aims at exploring objects under the study deeply, naturally, and comprehensively (Babbie, 2008). Therefore, this study analyzes the implementation of the sound governance dimensions based on the author's view explicitly stated in the research report.

In this research, the author focuses on the five critical dimensions of the concept of the sound governance which are the process, the structure, the values, the management, and the policy (Farazmand, 2004). Each dimension of the sound governance is described by using indicators; 1) Process, the stakeholders are involved in the interaction of the Mamminasata metropolitan area development process; 2) Structure, is the organization and the rules that direct the Mamminasata metropolitan area development process; 3) The values, the responsiveness and fairness embodied in building Mamminasata metropolitan area; 4) Management, is the provision of knowledges, technologies and resources contained in the Mamminasata metropolitan regional development; and 5) Policy, is the public participation in building the Mamminasata metropolitan area.

The collection of primary and secondary data in this study is done by conducting in-depth interviews, observations, documentations, and triangulation (Sugiyono, 2013) in the Bapppeda Office, Spatial Planning Institution, Highway Road Institution and the Regional Representatives Council (DPRD) of South Sulawesi province in each region belonging to the Mammi- nasata metropolitan area (Makassar, Maros, Gowa and Takalar).

The qualitative data analysis in this study was conducted in several stages according to Miles \& Huberman (in Lexi J. Moleong, 2012) as the following:

1. Collecting data through interviews with key informants supposed knowing Mamminasata development process. It is then followed by direct observations to the field to obtain the required data.

2. Reduction of data (data reduction) is the electoral process. It focuses on the simplification and transformation of the raw data taken by the author in the field. This process is held to find the practical information of each indicator related to the sound governance that is considered to be in line with the research purposes.

3. The data display, presenting the information in narrative form aiming at sharpening the understanding of the information that has been presented in each indicator description of the sound governance.

4. Drawing conclusion is the final stage. This is conducted carefully by verifying the data reviews on every dimension of the sound governance indicators taken in the field. It is expected that the data obtained can be tested their validity and can portray the overall development progress of the Mamminasata metropolitan region. 


\section{RESULT AND DISCUSSION}

\section{Process Dimension}

The development process of Mamminasata metropolitan region begins with the signing of a Memorandum of Understanding (MoU) of the integrated infrastructure development cooperation within the Mamminasata metropolitan area in October 19, 2003 by the regent and chairman of the local parliament in Mamminasata territory, witnessed by Governor of South Sulawesi and Chairman of Provincial Parliament of South Sulawesi. Regions incorporated in Mamminasata area are Makassar, Maros, Gowa and Takalar. This cooperation agreement was made because each area was not able to walk alone in solving the problems faced. Thus the South Sulawesi provincial government under the Department of Spatial Planning and Housing designed an agreement for a cooperation among the provinces and districts/ cities incorporated in Mamminasata regional development. As the core city of Mamminasata, Makassar has experienced an impact of the rapid growth in providing the civil society's needs. Thus the shortcomings owned by one region can be solved by other regions in accordance with the cooperation agreement.

Stakeholders involved in the development of the region Mamminasata are the Provincial Government of South Sulawesi that consists of Governor, Department of Spatial Planning and Housing coming beneath the UPTD Mamminasata, Regional Planning Institution and Local Parliament in South Sulawesi, Regents and Mayors in Mamminasata areas underscored by the Department of Spatial Planning, Regional Planning Institution and DPRD and related regional work units (SKPD). The civil society and society figures also take the significant role in the implementation of activities. They are assisted by JICA consultant (Japan International Cooperation Agency) which is an international side designing a master plan of the Mamminasata development in South Sulawesi.

All of the stakeholders conduct the coordination among the local governments throughout the Mamminasata region under the control of the South Sulawesi government. The real among that is held by the stakeholders started from planning, utilizing, and controlling of each development program in the field. Every single thing that needs to be discussed regarding the Mamminasata development, the Provincial Government invite all the stakeholders of each region to conduct meetings. It was illustrated in drawing an RTRW Bylaw No. 10 of 2003 on the Mamminasata Metropolitan Region and Regulation No. 9 of 2009 on Spatial Planning of South Sulawesi province Years 2009-2029. In formulating this rule, all the stakeholder were invited to have coordination meetings and were asked as well as to have two-way communications among all stakeholders working together.

For example, in the planning process of determining the location of the landfill agreed by the regional government of Gowa, the publishing of Presidential Decree No. 55 of 2011 on spatial planning of urban of Mamminasata becomes the reference in the implementation of priority programs of Mamminasata develop- 


\section{Organizational Structure Mamminasata Metropolitan Cooperation Agency}

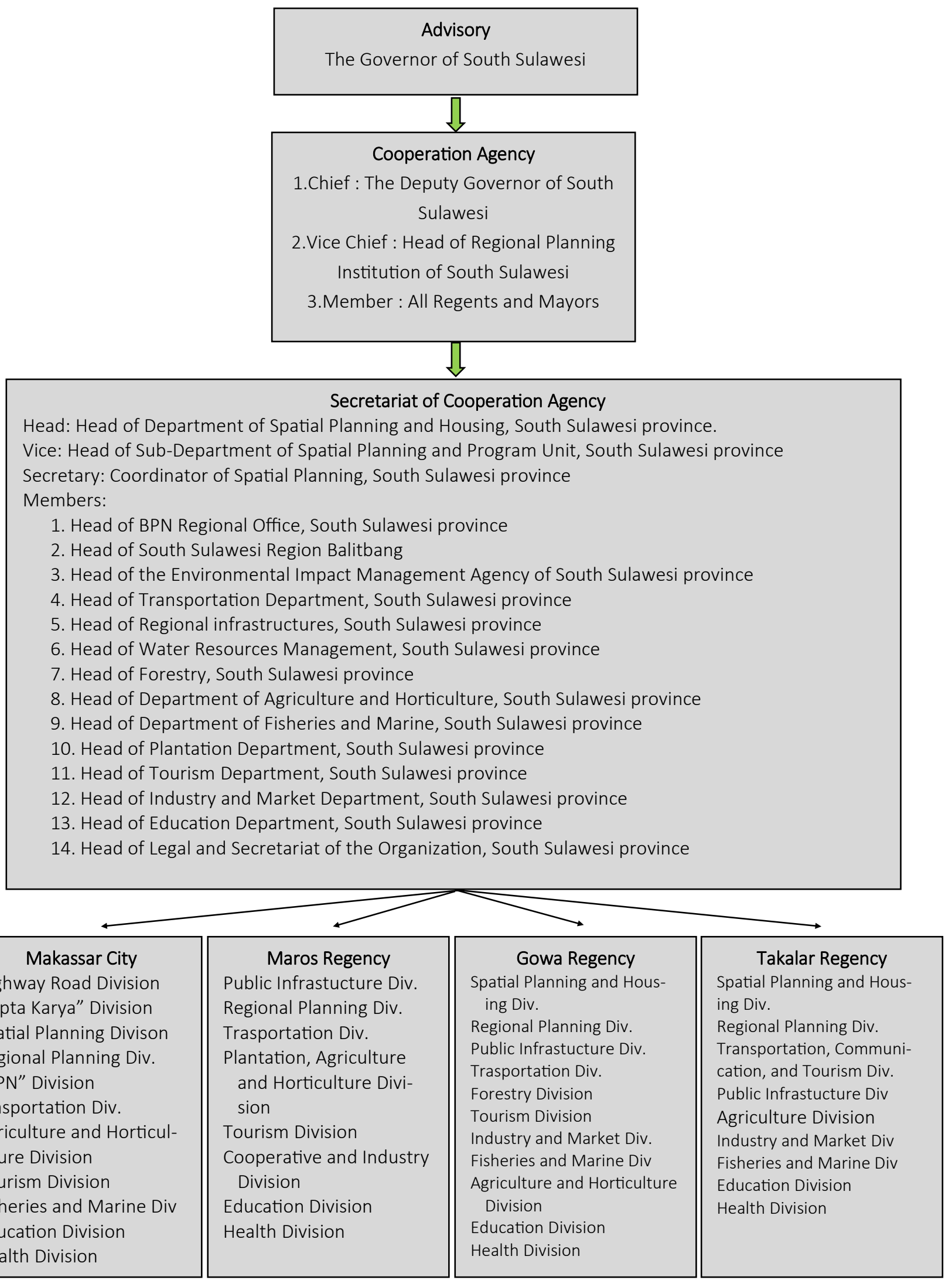

Figure 1. Organizational Structure of BKSPMM (Mamminasata Metropolitan Cooperation Agency)

2003 Source: Governor Decree No. 860,2003 
ment. The regional landfill is set to be located in Pattalasang, the District of Gowa. However at this stage of its implementation, local government of Gowa decided to move the location of the landfill to the District of Parangloe It is because the District of Pattalasang is planned for the development of office building complex of Gowa. This resulted in delays in the process of the Mamminasata regional landfill construction. Meanwhile, JICA has been providing assistance in the case of construction loan. It is necessary to revise the Presidential Decree no. 55 of 2011 to overcome the constraints faced for the location change of the regional landfill sites. However it is difficult to do so because there should be a very good coordination and re-negotiation among the related stakeholders.

The coordinations in Mamminasata construction consist of bot internal and external coordinations. The external coordination is the coordination among the regions through the government of South Sulawesi province. This coordination is conducted among the four areas under the province. For example, in the construction of Arterial Road Network in South Sulawesi which involves four areas, the coordination was conducted under Mamminasata territorial institution. While the internal coordination is the coordination carried out by each internal respective regions. For example, in designing the concept of Galessong beach, Takalar, it is carried out by the internal coordination among related sub-regional work units. The internal coordination is performed to advance the sub-regional areas by using their own concept of development. In the de- velopment process Mamminasata region, there are obstacles faced by stakeholders in the process of implementing activities. It pushes the related regions to always coordinate with other regions to find solutions. It reflects the Farazamnd's explanation (2004) that the sound dimension in the process of the sound governance has been implemented in the Mamminasata metropolitan area development. This is evidenced by the existence of the interaction among the related stakeholders in Mamminasata metropolitan area development. Moreover, internal coordination is also done by each region. This coordination continues to be done by inviting the sub-regional work units and local government to be involved in both planning and implementation of the development activities of Mamminasata. The results of this research also reinforce the findings of Nasution's study (2006) that the coordination and the commitment of the government are still low in term of Mamminasata development. For example, in deciding the location of Mamminasata regional landfill, the district government of Gowa is less committed to the deal that finally changed the location. It forces to conduct the reassessment in determining the location of the landfill.

\section{Structure Dimension}

In the Mamminasata metropolitan area development, it has been established the rules of an organization action that should be based on Decree No. 860 of 2003 concerning Mamminasata Metropolitan Cooperation Agency (BKSPMM). BKSPMM itself is filled by officials from the 


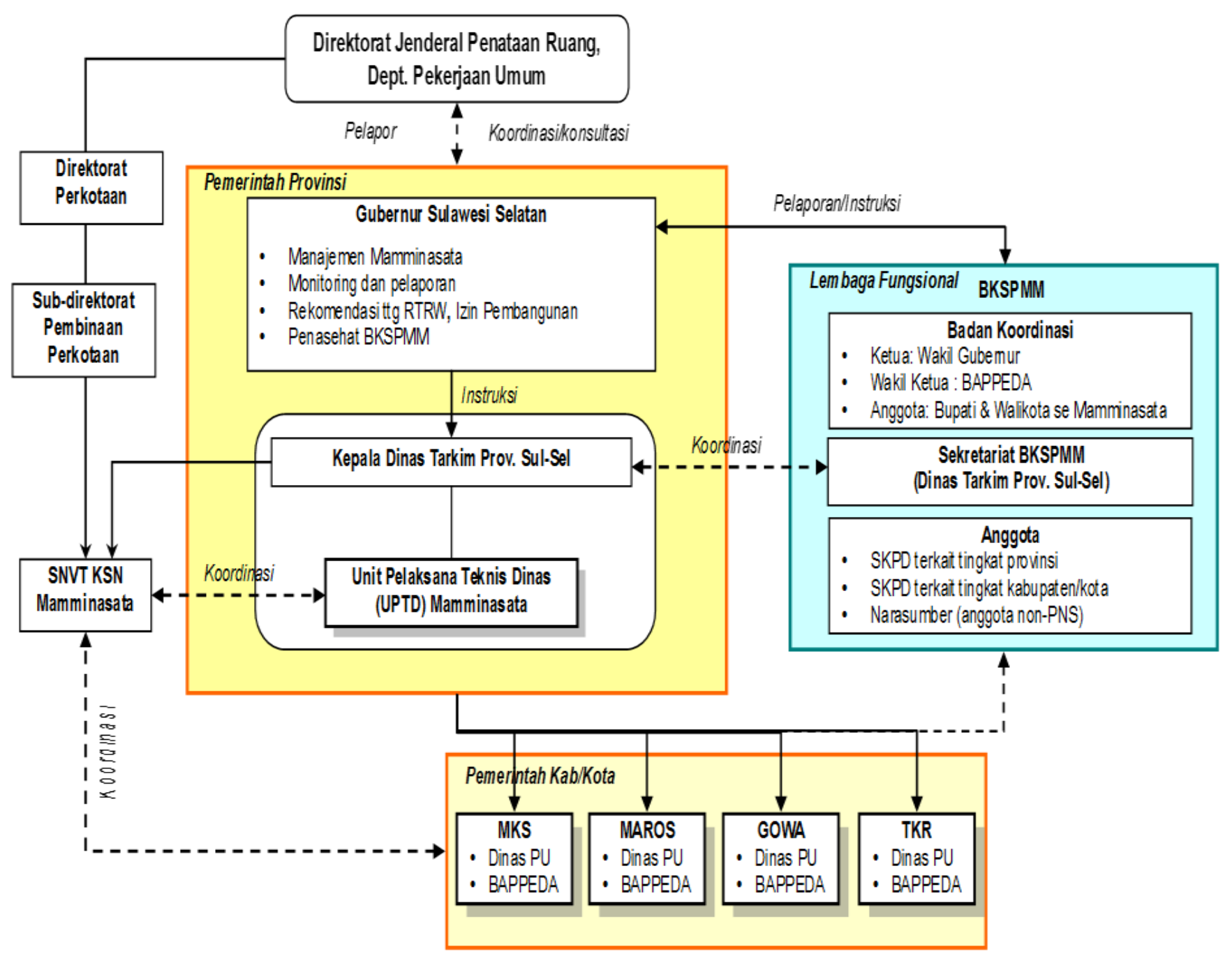

Figure 2. Structural Officers of BKSPMM

Source: Governor's Decree No. 1532 Year 2007

governor, regents, mayors and related subregional work unit (Figure 1).

The initial formation of the organization BKSPMM organizational structure, the governor of South Sulawesi took the advisory role. This cooperation organization is chaired by the Deputy Governor of South Sulawesi. Meanwhile, the members of the organization of this cooperation are both the regents and mayors. Furthermore, this organization has a cooperation agency secretariat chaired by head of department of Spatial
Planning and Settlement, South Sulawesi, comprising the relevant provincial government and district/ city associated with the Mamminasata construction.

As the development of the development process of Mamminasata metropolitan area, there are changes in the structure BKSPMM. This changes were made in accordance with the needs on the field regarding to the number of stakeholders at the district/ municipal, provincial, and central government that should be involved. 
Therefore, it needs to have a good coordination and clear roles inside both horizontally and vertically. Subsequently, in 2007 BKSPMM was determined as a Technical Unit forth in the Governor Regulation No. 16 of 2007. In 2009 the structure changes when BKSPMM's tasks were taken over by the UPTD Mamminasata technical unit as a structural element of the government. The implementation of the activities in the field is then controlled by UPTD Mamminasata that is established by the Governor Regulation No. 82 Year 2009. UPTD Mamminasata is one of elements of the Department of Spatial Planning and Housing of South Sulawesi province.

Mamminasata region is set to be a National Strategic Area (KSN). The development of this region gets a high priority from both the central government and the local governments.

There is a number of programs supported in its development. The existence of the importance of these programs and the desire to have the progress of the construction, then UPTD Mamminasata and BKSPMM were given a duty to carry out the monitoring of these programs for the smooth, the efficiency and the effectiveness of the implementation. For monitoring purposes, UPTD Mamminasata and BKSPMM through the support of JICA has set up a monitoring format that will be used to identify the progress and to facilitate the acceleration of the development. The coordination among the stakeholders conducted by UPTD Mamminasata can be seen in the Figure 2.
In supporting the implementation of the program BKSPMM, it needs to establish structural officials to carry out the function. The structural officials were established by occupying Governors Decree No. 1532 of 2007 about the establishment of BKSPMM officials. Here is the chart of arrangement of BKSPMM structural officials.

Composition of Officials Mamminasata Metropolitan Agency for Development Cooperation (Makassar, Maros, Sungguminasa/ Gowa, Takalar)

1. Advisory Board

Chairman: Governor of South Sulawesi Members: Derived from a variety of elements and be appointed by the chairman of BKSPMM.

\section{BKSPMM}

A. Chairman: Deputy Governor of South Sulawesi

B. Vice Chairman: Head of BAPPEDA, South Sulawesi Province

C. Members: 1. Mayor of Makassar,

2. Regent of Maros,

3. Regent of Gowa, and

4. Regent of Takalar.

D. Secretariat

1. Head: Head of Department of Spatial Planning and Housing, South Sulawesi province.

2. Vice: Head of Sub-Department of Spatial Planning and Program Unit, South Sulawesi province

3. Secretary: Coordinator of Spatial Planning, South Sulawesi province 
4. Members:

a. Head of BPN Regional Office, South Sulawesi province

b. Head of South Sulawesi Region Balitbang

c. Head of the Environmental Impact Management Agency of South Sulawesi province

d. Head of Transportation Department, South Sulawesi province

e. Head of Regional infrastructures, South Sulawesi province

f. Head of Water Resources Management, South Sulawesi province

g. Head of Forestry, South Sulawesi province

h. Head of Department of Agriculture and Horticulture, South Sulawesi province

i. Head of Department of Fisheries and Marine, South Sulawesi province

j. Head of Plantation Department, South Sulawesi province

k. Head of Tourism Department, South Sulawesi province

1. Head of Industry and Market Department, South Sulawesi province

m. Head of Education Department, South Sulawesi province

n. Head of Legal and Secretariat of the Organization, South Sulawesi province

o. Head of the Economic Development Bureau and the Secretariat of
Development, South Sulawesi province

E. Technical Unit: Officials assigned by the Chairman BKSPMM

F. Regional BKSPMM (derived from related SKPD set by regents/ mayors)

In drawing up the regulations on the Mamminasata construction, there are many steps that must be carried out involving a number of stakeholders. It can be started from the formulation of Regional Regulation (Perda) until the issuance of Presidential Decree (Decree) to regulate the development process of Mamminasata. The process of drafting the regulations involves multiple parties from the local government, central government, and international agencies such as JICA wich was very helpful in making a master plan for regional development of Mamminasata. In addition, JICA is also conducting feasibility studies, providing advices and training on Mamminasata development process. Furthermore, JICA is really important in the implementation stage of development to accelerate the actualization of Mamminasata.

The development of Mamminasata is an example for other national strategic areas because it has a clear organizational structure and strong regulations. The regulation controls the overall process of the development of Mamminasata. Besides, the rules are not only made by the provincial government, but also issued by the district/ city in the Mamminasata region in accordance with the characteristics of each area, but they are kept in line with the existing regula- 


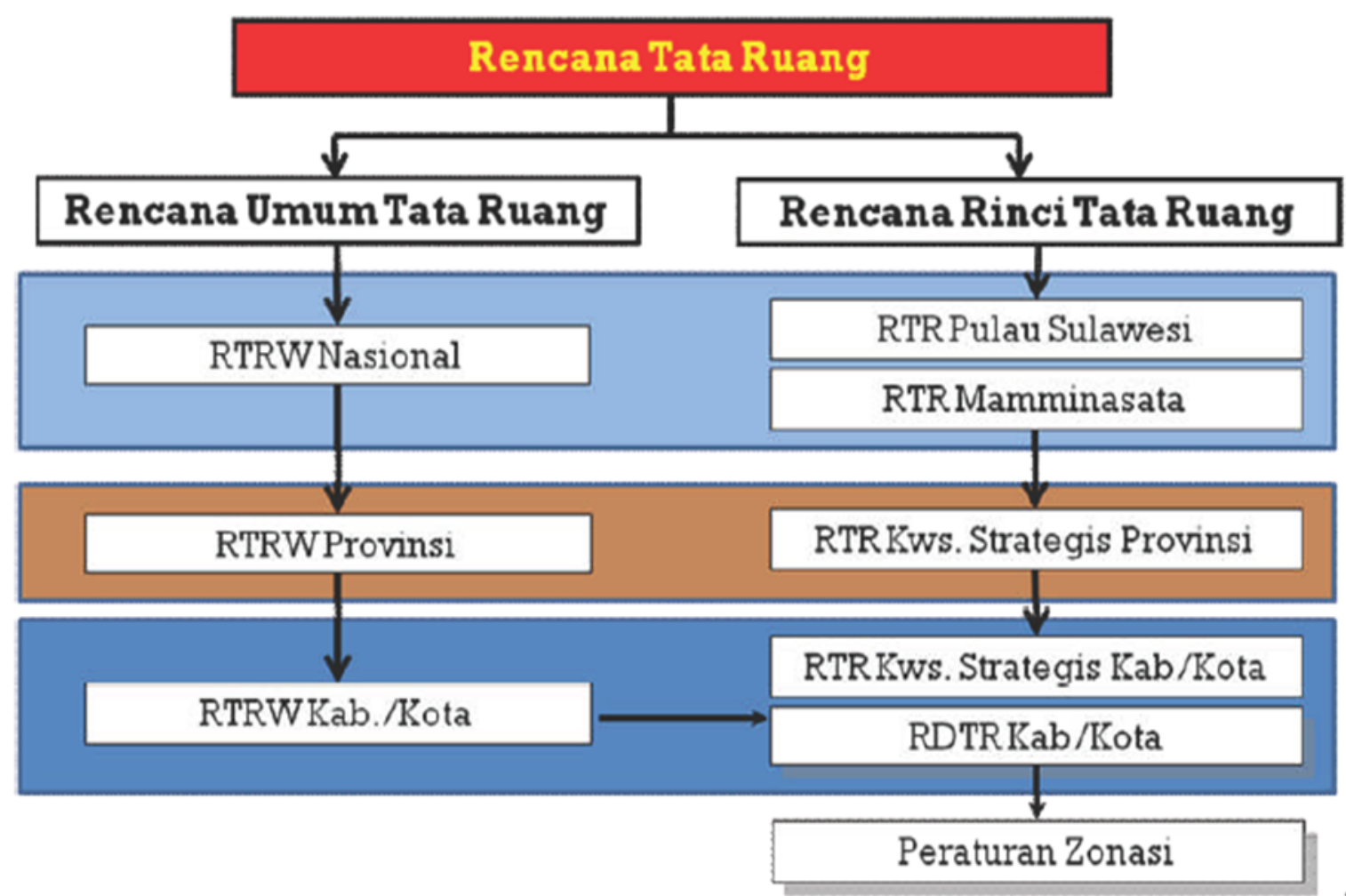

Figure 3. The Hierarchy of Spatial Planning in the Spatial Planning System

tions which finally make up the hierarchy. In addition to the implementation of development process of Mamminasata not only regulations from the central government, provincial governments needed, but also there should be rules governing the layout of the city. The regulations are made by the district/ city synergize with existing regulations. For example, in building Makassar, there is a Regional Regulation No. 4 of 2015 on Spatial Planning of Makassar 2015 - 2034, in district of Maros, there is a District Regulation No. 16 year 2012 on Spatial Planning Maros year 2012-2031, in district of Gowa, there is a District Regulation No. 15 year 2012 on Spatial Planning Gowa year 2012-2031, in district of Takalar, there is a Regional Regulation No. 6 of 2012 on Spatial Planning of Takalar year 20122031. All the regulations were established by each region which are kept in line with Presiden- tial Regulation No. 55 of 2011 on Spatial Planning of Mamminasata Urban. Figure 3 describing the hierarchy rules regarding to the Mamminasata spatial plan.

The President Regulation on Mamminasata becomes a reference for central, provincial, and regency/ city government in the development programs in Mamminasata. The district/ city no longer had the other regulations because all of them refer to the Mamminasata main rules. However, each district/ city can have a detailed plan in making their own regulations. For example Gowa-Maros has rules about the New Town area and they have been discussed in both BKPRD Provincial and Regency/ City.

Thus, the structure dimension according to Farazmand (2004) has been clearly implemented in Mamminasata area development. This can be seen from the implementation of the develop- 


\begin{tabular}{lll}
\hline No & Priority Programs & Location \\
\hline 1 & New City of Mamminasata & Maros and Gowa Regency \\
2 & Center Point of Indonesia (COI) & Makassar City \\
3 & Integrated Educational Area of Mamminasata & Gowa Regency \\
4 & Maritime Area of Takalar & Takalar Regency \\
5 & Industrial Area of Maros-Makassar & All regions \\
6 & Mamminasata Go Green & All regions \\
7 & Arterial Road Network & All regions \\
8 & Drink Water Installation & All regions \\
9 & Regional Landfill of Mamminasata & Gowa Regency \\
10 & IPAL Losari & Makassar City \\
11 & Primary Drainage & All regions \\
\hline
\end{tabular}

Table 1. Area Development Priority Program of Mamminasata Source: Data Analysis 2016

ment process of Mamminasata stipulated in Presidential Regulation No. 55 of 2011 on Spatial Planning of Mamminasata Urban. This Presidential Decree is a follow up from the Regional Regulation No. 9 of 2009 on Spatial Planning of South Sulawesi province years 2009-2029. In addition, each region has a rule related to the implementation of the development of Mamminasata which is set in line with the existing regulations. The rule-making involves all related stakeholders among district/ city government, the provincial governments, and the central government. Each rule-making also involves academicians, civil society and the international organizations, JICA. JICA is absolutely instrumental in the development planning of Mamminasata. It begins with the process of the implementation of a feasibility study on any area of cooperation in the Mammiasata region until the last stage of the issuance of Presidential Decree No. 55 of 2011.

\section{Value Dimension}

The sound governance raises clean and dynamic values underlying the process and structure dimensions (Farzamand, 2004). In the development of Mamminasata metropolitan area, the local governments have the responsiveness to the needs of the areas incorporated in the construction. Any proposal on the needs of each region is collected. They are the fundamental reasons to create regulations for the implementation of the area development programs. Mamminasata program is a response of the local government when South Sulawesi Province is no longer able to solve their own problems, then it is done in a cooperation with other regions. This cooperation is carried out to complement inter-regionals' short- 
ages. Thus, the regional supports the cooperation inter-regionals formed by the government of South Sulawesi province.

The responses coming from the local governments related to Mamminasata development program is very well. They are ready to host the program to prepare Mamminasata as a National Strategic Area (KSN). It can be seen in the drawing of regulations that every region has had its own rules that support the Mamminasata regional development programs. The proposals made by the government of the province are greatly responded by local governments and municipalities in the Mamminasata region.

Metropolitan area development involves four regions, namely Makassar, Maros, Gowa and Takalar. By involving many areas incorporated therein, the development of this area has been promoting the diversity of each region with a justice for every region. The justice is certainly adapted to the potential of each region. The development of the region also has put forward the complexity of every region. The complexity comes from the region in terms of both its potential and constraints that need to be resolved. Therefore in the implementation of this program, justice is indispensable so that the local government can formulate the needs of their own regions that have been set in the existing regulations.

With the actualization of the justice in term of Mamminasata development, each region has the same role in accordance with its potential. Each area is given the opportunity to make a proposal to the provincial government in accordance with the needs of the 11 programs related to program priorities of the development of Mamminasata metropolitan area. The justice is reflected from the decision of the location of each program in accordance with the potential of each area. The stipulation of the location of the regional development priorities of Mamminasata program that embodies the values of justice can be seen in the table 1 .

Based on the table 1, from 11 priority programs there are some of them that are built for all regions. For example, Maros-Makassar industrial regional development, Mamminasata Go Green program, Arterial Road Network program, and The Primary Drainage and Water Supply Program. Related to the industrial area, in accordance with the Presidential Decree Number 55 year 2011, the development of industrial area in Mamminasata urban areas is planned each in Makassar (KIMA), Gowa (Kiwa), Maros (Kiros), and Takalar (KITA). Furthermore, there is also a specific program which was only built in one area only to match its potential. For example, the IPAL Losari program and Center Point of Indonesia (COI) are fit only built in Makassar, the development of Regional Landfill of Mamminasata and the Integrated Educational Area of Mamminasata in Gowa district, and the construction of the New City of Mamminasata built in two areas, namely in Maros and Gowa. Therefore, the determination of the location of all development priority programs are clear according to the potential of the area and on the agreement of each local government as stipulated in Presidential Decree No. 55 of 2011. 
Thus, according to Ali Farazmand (2004), the value dimension has been applied to the development of the Mamminasata metropolitan area. It is obvious that all stakeholders including the government of South Sulawesi province, the central government and the local government of district/ city has strong responses by establishing inter-regional cooperation in addressing the problems and meet a variety of needs. The local government of each district/ city is responding well, feels the need, and supports any development program. Every program is clearly built in accordance with the potential and the needs of each region and it is agreed by all regional that is in cooperation.

The results of this study also clarifies the research findings (Nasution, 2006) which says that the coordination and the commitment of the local government is still low due to the inequality of the development from one region to another, so there are some areas that feel disadvantaged. However, this study found there has been an evenness of the development in each priority program in accordance with the potential and the needs of each region establishing a sense of justice for each region.

\section{Management Dimension}

In term of management dimensions, it needs to give the knowledge, the technology, and the resources with the renewal through research, training, and people capacity building. The absence of a good management will impact in the failure of governance (Farazmand, 2004). In the development of Mamminasata metropolitan area involving four districts/ cities, the local govern- ment should disseminate to each area. The dissemination should be started from the planning stage up to the implementation stage so the implementation of development goes well. The dissemination can be carried out in the form of meetings and workshops so that the stakeholders can recognize any programs to be carried out.

As efforts in improving the knowledge of the stakeholders about Mamminasata regional development, in addition to dissemination conducted by the provincial government, each region must also conduct separate discussions to synchronize the programs being carried out to those drawn up by the region itself.

The implementation of the development of Mamminasata metropolitan area has been using GIS technology (Geographic Information System) for IT-based spatial planning. GIS is a unified system consisting of various components, not only the hardware and the software but also correct geographical data and human resources to formulate and to analyze issues that determine the success of GIS. Initially GIS was promoted by JICA to be applied in the implementation of the development of Mamminasata. In the beginning, training is conducted for the officers of the government in the application of GIS. However, the use of this technology is still limited because of the lack of resources and limited facilities and infrastructures. It looks at the availability of GIS that not all regions have because of constrained budgets. In addition, the use of GIS is still experiencing problems due to the government officers who have been trained as operators for using GIS move to other work sites. This occurs because 
the employees who attend training are transferred or promoted to another office. This situation absolutely obstructs the efforts on the GIS application.

Therefore, in increasing the capacity of human resources, there should be always training. The training can be held by the provincial government by inviting officials in the lower government unit. In improving human resources, it is necessary to reform them conducted by the local government. The training also needs to be conducted with the involvement of academicians in accordance with the discipline needed. The training should also be given up to the village level in enhancing the human resources, especially in the use of technology.

Mamminasata metropolitan area development has actually had the resources. However, the availability of both the natural resources and the human resources in the region are still limited. It is seen that not all regions have the natural resources. This forced the government to distribute raw materials from one to other areas which work together in the development of Mamminasata. For example, in the compliance of drinking water, Makassar City Government holds cooperation with the Government of Maros and Gowa. The human resources are also still limited, but the provincial government has always undertaken training to improve the quality of employees by involving academicians.

In the development of Mamminasata, the provincial government conducts the dissemination in spreding out knowledge about Mamminasata development concepts to the stakeholders at the districts/ cities. The dissemination is conducted continuously by visiting each region to provide information related to the construction of Mamminasata. In addition, the dissemination is also done by inviting stakeholders to Galeria Mamminasata to attend seminars and workshops in collaboration with the academicians and JICA consultants.

An indicator of technology explains that the GIS technology has already been implemented in the construction Mamminasata. However it is still not effective yet in the implementation in the field due to the employees working as the operators of the GIS move to other ofices. This occurs because the employees who attend training are transferred or promoted to another office. This situation absolutely obstructs the efforts on the GIS application. It is also constrained by the supply of GIS equipment because of financial constraints for the procurement of the goods in each region.

At last, the author can say that the dimension management in the sound governance has been implemented well in the development of Mamminasata metropolitan region. It is evidenced in the development of the Mamminasata metropolitan region, officers from any region are given disseminations, workshops and training in the use of technology. Those are the attempts to increase the capacity of the human resources in carrying out their duties. With the increased capacity, the government officers are hoped to successfully carry out their duties conformed to the vision and mission of the development of Mammi- 
nasata.

\section{Policy Dimension}

There is a participation of the legislature to express the desire of the civil society related to the policy in the development of Mamminasata metropolitan area. The policy is established as Regional Regulation no. 9 of 2009 on Spatial Planning of South Sulawesi province 2009-2029. The policy-making involves the civil society by conducting dissemination to the public figures and also parliament to convey the aspirations of the civil society. The civil society is involved directly in the decision-making of the implementation of Mamminasata development. With the $\mathrm{KSN}$, the government requests the support of the public in the policy making and the implementation. In each policy making, public participate by presenting the invitation to voice their wishes in an FGD (Focus Group Discussion). The citizens are also invited to express their aspirations related to the provision of the clean water in the metropolitan area and the construction of the New City of Mamminasata. They are asked to participate directly in terms of land acquisitions.

The government has encouraged the citizens to participate directly as in land acquisition and to provide information to the government about the conditions on the ground. The government is encouraging them by applying incentives and disincentives. Incentives are held in regions that want to be facilitated to accelerate the growth by ease the permit affairs at low cost. While conversely, disincentives aims at reducing the rate of the growth assessed exceeding the threshold by inhibiting the license affairs at high costs and even with the revocation of the license. Thus, it can be concluded that the policy dimension of the sound governance has been applied in the development of Mamminasata metropolitan area.

Associated with the innovations applied in the regional government, South Sulawesi province has made the innovation in developing the regional. The innovation is established by building a metropolitan area of Mamminasata involving cooperation among the local governments. This cooperation is based on the signing of the Memorandum of Understanding among the Governor, the Provincial Parliament, mayors and regents, and the chairman of Parliament under Maminasata territory as well in October 19, 2003 on the Integrated Infrastructure Development Cooperation written in the Governor Decree of South Sulawesi no. 860 of 2003 on the Establishment of the Development Cooperation Agency (BKSP) of Mamminasata Metropolitan. This decision is a follow up of the South Sulawesi Provincial Regulation no. 10 year 2003 on Spatial Plan which sets Mamminasata Metropolitan Development Cooperation Agency (BKSP) as an organizational network (network organization) which serves to control and to supervise the use of the city space and to optimize the utilization of its potential in building the metropolitan area of Mamminasata.

Mamminasata concept is the result of cooperation with a of Japan international nongovernment organizations (NGO), namely Japan International Cooperation Agency (JICA). The cooperation conducted with JICA is started from 
planning the Mamminasata concept up to implementing it which is also supported by the community, the private sectors, and the investors (Fajar, October 13, 2005). In this partnership, international element, JICA fills a role for the international side in the governance associated with the demands of the concept of the sound governance.

\section{CONCLUSION}

Based on the results of the research and the discussion as it has been described previously, it can be concluded that the dimensions of sound governance have been implemented in the development by emphasizing the diversity, complexity, and intensity of both the internal and the external Mamminasata metropolitan area. It is also seen that the concept of good governance has only three actors who play the roles namely the government, the society, and the private sector. However, this study found that there are an additional element taking an important role in strengthening the rule which is international element, such as Japan International Cooperation Agency (JICA). JICA really play a central role in the development of the Mamminasata metropoli$\tan$ region. This international element encourages the emergence of the concept of the sound governance that becomes an alternative concept for developing countries in conducting a strong and innovative governance to face global challenges.

In the implementation of the process dimension, since 2003 the local government involving in creating a memorandum of understanding (MoU) has conducted the coordination among districts/ cities under the supervision of the South Sulawesi provincial government, UPTD Mamminasata, and BKSPMM (Mamminasata Metropolitan Development Cooperation Agency). The coordination is also held among the SKPD in its own internal areas. This coordination is started from the planning phase up to the implementation phase of the development program of Mamminasata.

In the structure dimension, the Government has established an organizational structure called the Mamminasata Metropolitan Development Cooperation Agency (BKSPMM) as a forum for coordination in building Mamminasata region. This institution has a clear regulation to steer. It has an organized personnels consisting of various elements of regional governments that cooperate on the development of Mamminasata.

In the values dimension, the Government established the development programs based on the responsiveness of local government of Mamminasata area in seeing the development of the areas that is no longer able to overcome the problems of its own region. Therefore, the government established the cooperation among the four regions incorporated within the Mamminasata (Makassar, Maros, Gowa, and Sungguminasa) which will strengthen each other in the regional development. The priority programs in the master plan of Mamminasata development have established justice for each area by locating a construction program in accordance with the needs and the potentials as well.

In the management dimension, the stakeholders involved already have the knowledge on 
the concept of the development of Mamminasata after getting the desiminnation held by the government of South Sulawesi province. Mamminasata regional development is supported by the use of GIS (Geographic Information System) which is also known as the Geographic Information System (GIS). The technology serves to organize the space with technology-based system in order to achieve both the effectiveness and efficiency in the development process. However, in execution, the use of this technology experienced problems due to the employees operating the GIS move to another office which is caused by mutations or promotion which means that no one to replace them. That is why the GIS application is not running properly. In addition, the human resource development is still limited in Mamminasata. The government has been conducting trainings collaborating with the academicians and JICA consultant to improve the performance capacity of government officers.

In the policy dimension, the civil society is encouraged by the local governments either to participate directly in the policy making and in the implementation of priority programs of the development. The government is encouraging them by applying incentives and disincentives. Incentives are held in regions that want to be facilitated to accelerate the growth by ease the license affairs at low cost. While conversely, disincentives aims at reducing the rate of the growth assessed exceeding the threshold by inhibiting the license affairs at high costs and even with the revocation of the license.

Based on the findings in this study, the stakeholders need to consider several issues related to the development of Mamminasata metropolitan region in order to actualize both the sound governance and the innovative one. Several suggestions from this study that can be used as the practical implications are as following:

1. The local governments need to create a strong commitment in drawing the Memorandum of Understanding (MoU) to establish a regular coordination among the stakeholders so that the implementation of the development priorities programs run well.

2. The use of technology such as GIS (Geographic Information System) in the construction of Mamminasata region is muchneeded. The government needs to provide facilities and infrastructures in all areas of collaboration, thus simplifying both the data processing and presentation to meet the effectiveness and efficiency of the field activities.

3. In conducting either the training on the use of GIS or other training, the government should choose employees whose the status is staff and makes them as permanent staffs who work specifically for GIS.

4. The Government of the districts/ cities needs to establish sub-regional technical unit (UPTD) in order to strengthen the coordination with Mamminasata sub-regional technical unit.

5. This study has weaknesses because not all dimension is described regarding to the sound governance practice in developing countries, particularly those related to Mamminasata regional development. Therefore, the author 
expects that the further research can overcome the weaknesses of this research by involving the five other dimensions that are the constitution dimension, the organizational and institutional dimensions, the sector dimension, the international power dimension, and the of ethics, accountability, and transparency dimension.

\section{REFERENCES}

Achidsti, Sayfa Auliya. 2011. Pembangunan di Negara Berkembang. Dalam Agus Pramusinto \& Erwan A.P. 2012. Indonesia Bergarak; Percik Pemikiran Komunitas Sekip untuk Perubahan. Yogyakarta: MAP dan MKP UGM.

Babbie, Earl. 2008. The Basics of Social Research. Belmont: Thomson Wadsworth. Fourth Edition.

Creswell, John W. 2014. Research Design Pendekatan Kualitatif, Kuantitatif dan Mixed. Yogyakarta: Pustaka Pelajar.

Domai, Tjahjanulin. 2011. Sound Governance. Malang: Universitas Brawijaya Pers.

Farazmand, Ali. 2004. Sound Governance, Policy and Administrative Innovations. Westport London: Praeger Publisher.

Gant, George F. 1979. Development Administration: Concepts, Goals, Methods. London: The University of Wisconsin Press.

Moleong, Lexi. 2012. Metodologi Penelitian Kualitatif. Bandung: PT Remaja Rosdakarya.

Noor, Irwan. 2013. Desain Inovasi Pemerintahan Daerah. Malang: UB Press.

Pratikno. 2007. Kerjasama Antar Daerah: Kompleksitas dan Tawaran Format Kelembgaan. Program S2 PLOD. UGM. Yogyakarta.

Osborne, Stephen P. 2010. New Public Governance. Routledge: Taylor \& Francis eLibrary
Sugiyono. 2013. Metode Penelitian Kombinaso (Mix Methods). Bandung: Alfabeta.

Weidner, Edward W. 1970. Development and Innovational Roles, in Weidner(ed.), Development Administration in Asia. Durham: Duke University Press.

Batubara, Alwi Hasyim, 2006. Konsep Good Governance dalam Konsep Otonomi Daerah. Jurnal Analisis Administrasi dan $\mathrm{Ke}$ bijakan, volume 3, Nomor 1 Januari-April 2006.

Hartmann, Andreas. 2006. The Role of Organizational Culture in Countruction Firms. Construction Innovation; 6: 159-172

Holidin \& Handini. 2014. Sound Governance Analysis in the Innovation of Traditional Market Revitalization and Street Vendors Management. International Journal of $A d$ ministrative Science \& Organization, January 2014 Volume 21, Number 1.

Hidayat, dkk (2015). Penerapan Dimensi Sound Governance dalam Pelayanan Publik di Kantor Samsat Kabupaten Gowa. Kolaborasi Jurnal Administrasi Publik, Vol. 1, No.1, hal. 30-40, ISSN 2442-9498.

Keban, Yeremias, T. 2007. Membangun Kerjasama Antar Pemerintah Daerah Dalam Era Otonomi. Jurnal Ilmu Pemerintahan Indonesia. Jakarta.

Lin, Chief-Yu. 2007. Factors Affecting Innovation in Logistics Technologies for Logistics Service Providers in China. Journal of Technology Management in China, Vol. 2 No. 1. P. 22-37.

Nasution, Adnan, 2006. Faktor-faktor yang Mempengaruhi Implementasi Kebijakan Rencana Tata Ruang Wilayah Metropolitan Mamminasata Sulawesi Selatan. TesisUGM: Yogyakarta.

Nugraha, Agus (2012). Kebijakan Seleksi Calon Pegawai Negeri Sipil Daerah (CPNSD) dalam Perspektif Sound governance. Jurnal kebijakan dan manajemen PNS, Vol. 6 No. 1, ISSN 1978-7103.

Oughton, Christine, Mikel Landabaso \& Kevin Morgan. 2002. The Regional Innovation Paradox: Innovation Policy and Industial Policy. Journal Of Tachnology Transfer. 27, P. 97-110. 
Parnaa, Ott and Nick von Tunzelmann. 2007. Innovation in the Public Sector: Key features influencing the development and implemetation of technologically innovative public sector service in the UK, Denmark, Finland and Estonia. Information Policy, 12 109-125.

Sangkala. 2011. Praktek Good Governance dan Implikasinya terhadap Konsep dan Idiologi Penyelenggaran Pemerintahan dan Administrasi Di Negara -Negara Berkembang (Sound Governance Sebagai Antitesis Dari Good Governance). Jurnal Ilmu Administrasi Vol.1 No.1 Juni 2011

Tjahjanulin. 2011. Interregional Cooperation Policy In Sound Governance Perspective. Advances in Natural and Applied Sciences, 5(3): 235-241, 2011 ISSN 1995-0772.

Xie, Wei and Richard Li-Hua. 2009. What will make China an innovation-oriented country?. Journal of Knowledge-based Innovation in Chine, Vol. 1 No. 1 P 8-15.

Ugart, Anggi S. Menanti Kota Metro 2020, Pacu Pembangnan Interkoneksitas. Fajar, 13 Oktober 2005
Buku Panduan Mamminasata, 2011

Keputusan Gubernur No. 1532 tahun 2007 tentang Penetapan Personalia BKSPMM

Laporan Monitoring dan Evaluasi, 2014

Laporan Penyelenggaraan Pemerintahan Daerah (LPPD) Pemerintah Sulawesi Selatan Tahun 2007.

Laporan Penyelenggaraan Pemerintahan Daerah (LPPD) Pemerintah Sulawesi Selatan Tahun 2009.

Peraturan Daerah Provinsi Sulawesi Selatan No. 10 Tahun 2003 tentang Rencana Tata $\mathrm{R} u$ ang Wilayah Metropolitan Mamminasata

Rencana Kerja Pemerintah (RKP) tahun 2015

Rencana Kerja Pemerintah (RKP) tahun 2012

Surat Keputusan Gubernur Sulawesi Selatan Nomor 860 tahun 2003 tentang Pembentukan Badan Kerjasama Pembangunan (BKSP) Metropolitan Mamminasata (Makassar, Maros, Sungguminasa/ Gowa dan Takalar) 